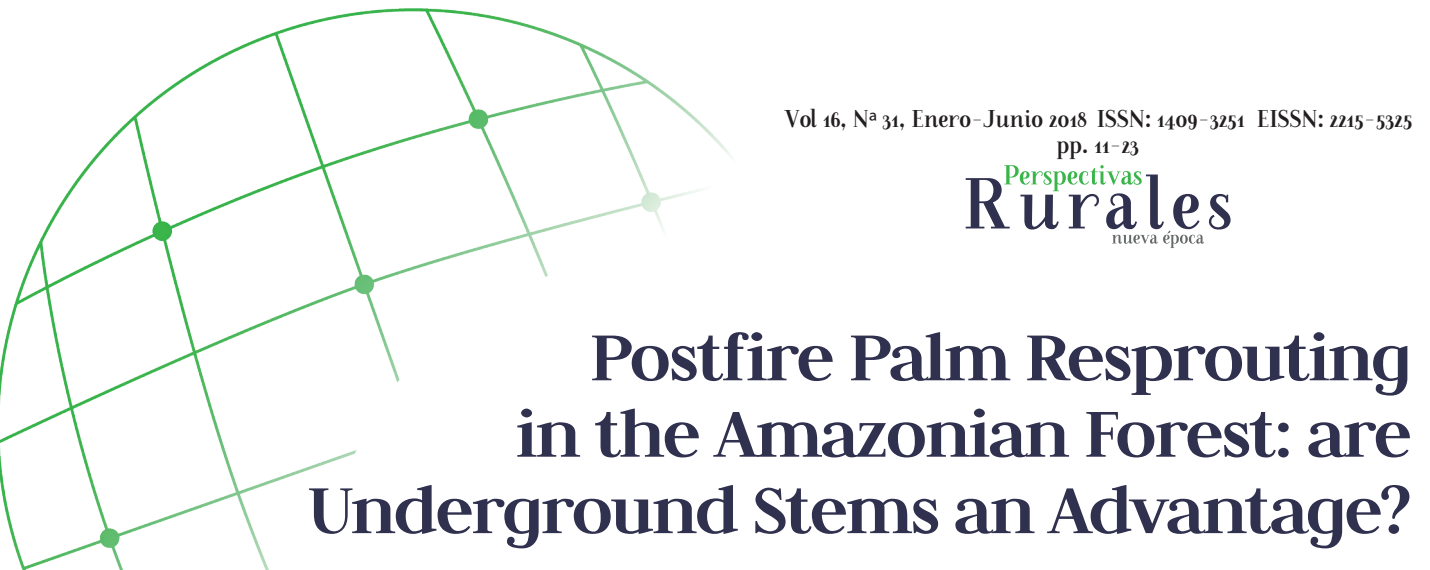

\title{
Brote posfuego de la palma en el bosque amazónico: ¿son los tallos subterráneos una ventaja?
}

Marcus Vinicius Athaydes Liesenfeld

Federal University of Acre, Brasil.

athaydes@gmail.com

\section{Gil Vieira}

National Institute of Amazonian Research, Brasil.

scallop1957@gmail.com
Aceptado: 14/09/2017

Publicado: 30/06/2018
DOI: http://doi.org/10.15359/prne.16-31.1

\begin{abstract}
Despite the fire is the least studied impact among the current disorders affecting tropical American palms, the Arecaceae family is ideal for studies of resilience and impacts. The present study was the first to quantify and describe the postfire palm resprouting in the Amazon rainforest. We tested a set of juveniles and mature individuals of 10 palm species, to assess which morphological characteristics are related to postfire mortality or resprouting, so the aim of this study was to 1 ) record the possible response strategies of understory palms to fire disturbance; 2) compare the postfire responses between undergroundstemmed and aerial stem species, and 3) compare the postfire responses between species with and without clonal ability. For all species of palm trees subjected to this
\end{abstract}

experiment, the fire was not capable of eliminating all individuals, and after $\sim 140$ days after fire, we found that aerial stems had more basal sprouts than underground stems. Underground-stemmed species had more apical regrowth than for the aerial stems species. The number of resprouting individuals is greater in clonal species than in non-clonal species. Therefore, we conclude that palm species in the western Amazon have differential responses to fire impact.

Keywords: surface-fire; fire ecology; regeneration

\section{Resumen}

La familia Arecaceae es ideal para estudios de resiliencia e impactos; sin embargo el fuego es el impacto menos estudiado entre los disturbios actuales que afectan las palmas tropicales americanas. El presente estudio 
fue el primero en cuantificar y describir el brote posfuego de las palmas en la Selva Amazónica. Para evaluar las morfologías que se relacionan con la mortalidad o brotación posfuego experimental, hicimos: 1) analizar las estrategias de respuesta de las palmas del sotobosque a la perturbación del incendio; 2) comparar las respuestas al fuego entre las especies de tallo subterráneo y de tallo aéreo y 3) las respuestas al fuego entre especies con y sin habilidad clonal. Para las palmeras sometidas a este experimento, el fuego no fue capaz de eliminar todos los individuos y después de $\sim 140$ días, encontramos que los tallos aéreos tenían más brotes basales que los tallos subterráneos. Las especies de tallos subterráneos tienen más rebrotes apicales que las especies de tallos aéreos. El número de individuos con brotes es mayor en especies clonales que en especies sin esta habilidad. Por lo tanto, concluimos que las especies de palmeras de la Amazonia occidental tienen una respuesta diferencial al impacto del fuego.

Palabras clave: fuego de superficie; ecología del fuego; regeneración

\section{Introduction}

The resprouting strategy for higher plants seems to be important when considering disturbances, among these the fire and climate change. Yet little is known of the characteristics involved in the resprouting processes of most plant species, which has motivated several authors to implement research with the evolutionary and functional aspects of this conditional plant morphology (Bond and Midgley, 2003; Clarke et al., 2013; Pausas and Keeley, 2014). In order to explain the resprouting mechanism, it is essential to understand the evolution and diversity of species, for then predict changes in vegetation in the context of global climate changes (Hirota et al., 2011; Clarke et al., 2013).

Fire is one of the most important drivers of change in ecosystems. Fire in the humid forest seemed a contradiction until a few years ago. Today, the rainforest is experiencing an increase in forest fires, due to the processes of climate global change and interaction of these with the lack of the forest's ability to maintain its natural moisture, especially on the edges, coupled with the slash and burn culture (Cochrane et al., 1999; Coe et al., 2013; Morton et al., 2013; Liesenfeld et al., 2016). Forests fires in the Amazon are a reality, but the interest in this theme has increased only recently.

The positive selection caused by fire is related to the species morphology and physiology. In this context, the suppression of aboveground plant biomass does not imply the individual death, because it keeps the resprouting ability (Keeley et al., 2000; Verdú et al., 2007). Understanding the ability of postfire 
plants regrowth, as an adaptive strategy linked to the resilience, can reveal information about the dynamics of populations after disturbances (Vesk and Westoby, 2004; Silvestrini et al., 2011; Clarke et al., 2013; Rogers et al.; 2015).

Palms are particularly resistant to the impact of fire (Tomlinson, 1979; Abrahamson, 1999; Wuschke, 1999; Miola et al., 2010; Aponte et al., 2011) so the family is ideal for studies of resilience and impacts, although fire is the least studied impact among the current disorders, affecting tropical American palms (dry and cold extremes, over-exploitation of resources and habitats conversion). Populations of determined palm species can become dominants in altered environments. In the east of the Amazonia the babassu is one of the main species regenerating in the intensive cattle-raising or in the abandoned areas (Rocha et al., 2016).

The objective here was to test a set of juvenile and mature individuals of ten understory palm species, to assess which morphological characteristics or attribute are related to mortality or resprouting of these species, after experimental fire. Thus, we aimed to: 1) record the possible response strategies of understory palms to surface fire disturbance; 2) compare the postfire responses between aerial stem and underground-stemmed species, and 3) compare postfire responses between species with and without clonal ability.

\section{Material and methods}

The study was carried on the edge of an Open Forest With Palms (Floresta Aberta com Palmeiras) in the Cruzeiro do Sul municipality, Acre, Brazil $\left(74^{\circ} 5^{\prime} \mathrm{S}\right.$ and $\left.72^{\circ} 22^{\prime} \mathrm{W}\right)$ - figure 1 . The fire was applied experimentally (figure 2), with a non-evasive method, burning directly 169 juveniles and mature individuals of 10 understory palm species (table 1).

The experiment was divided into three phases. In Phase I $n=169$ juveniles and mature individuals of the understory palms were randomly sampled. Each individual had leaf number and height of the stems measured. In Phase II, each individual was subjected to controlled burning, ignition by kerosene, in a $1 \mathrm{~m} 2$ protected area close to the stem. The temperatures were sampled with two K thermocouples: (T1) base of the plant temperature and (T2) environment temperature (figure 2). Full range of fire: 360 s. In phase III, 140 days postfire, was obtained the leaf scorch proportion, stem mortality and resprout per individual.

Postfire palm resprouting in the amazonian forest: are underground stems an advantage? Marcus Vinicius Athaydes Liesenfeld, Gil Vieira 
The burnings happened in Amazonian summer (August and September 2013), always in the midday period (11h00min and $17 \mathrm{~h} 00 \mathrm{~min})$. In order to verify the distribution of variable values, we tested the normality and variability using the Kolmogorov-Smirnov test. Prior to the analysis, the variables of the historictemperature were standardized. The Mann-Whitney test (two tailed) was used to verify the postfire response between groups of individuals with aerial stems and one with underground stems; and also in the comparison of postfire response between clonal ability groups. Kruskal-Wallis test was used for distribution comparison of postfire response between species. For all tests, a significance $p<$ 0.05 was adopted. Analysis were conducted in IBM SPSS $20^{\circ}$ and in R 3.0.3.

The parameters followed in the simulations describes the surface fire with $30 \mathrm{~cm}$ maximum height, $50 \mathrm{~kW} \mathrm{m-1}$ intensity and $760 \mathrm{oC}$ of maximum temperature, with propagation speed ranging from 0.1 to $0.35 \mathrm{~m} \mathrm{~min}-1$ (Uhl and Kauffman, 1990; Michaletz and Johnson, 2007; Krieger F et al., 2017).

The safety procedures followed the security protocol for prescribed fires, which allows the controlled burning for scientific purposes. The authorization was obtained through the certificate number 22/ 2012 granted by IMAC (Environment Institute of Acre - Brazil), and all the safety procedures required for controlled burning have been adopted.

\section{Results and discussion}

There was no significant time-temperature-story variation between individuals during the burn: all plants received almost the same range of temperatures $(f=1,883 ; p=0,057)$. The first responses began approximately 35 to 40 days postfire. The species that first responded to fire impact were Bactris maraja, Chamaedorea pauciflora and Hyospathe elegans, in adult stage. These individuals had regrowth/of their apical meristems. Juveniles of Attalea maripa, Geonoma acaulis and Astrocaryum ulei also began apical regrowth in this period directly from the underground meristem.

Postfire palm resprouting in the amazonian forest: are underground stems an advantage? Marcus Vinicius Athaydes Liesenfeld, Gil Vieira 


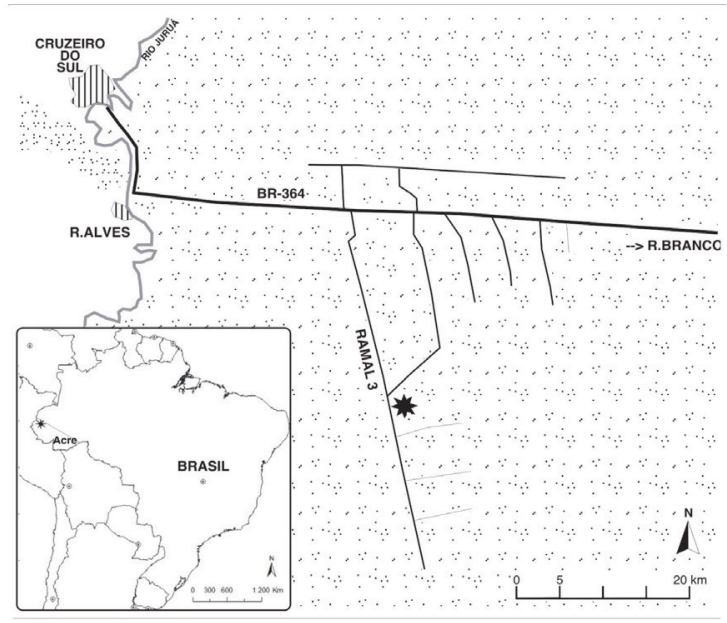

Figure 1. Location of study area (black asterisk) - 7055'19”S 72²4'23”, Cruzeiro do Sul municipality in Acre State, Brazil; parallel lines: urban areas of municipalities; hatched: continuous forest.
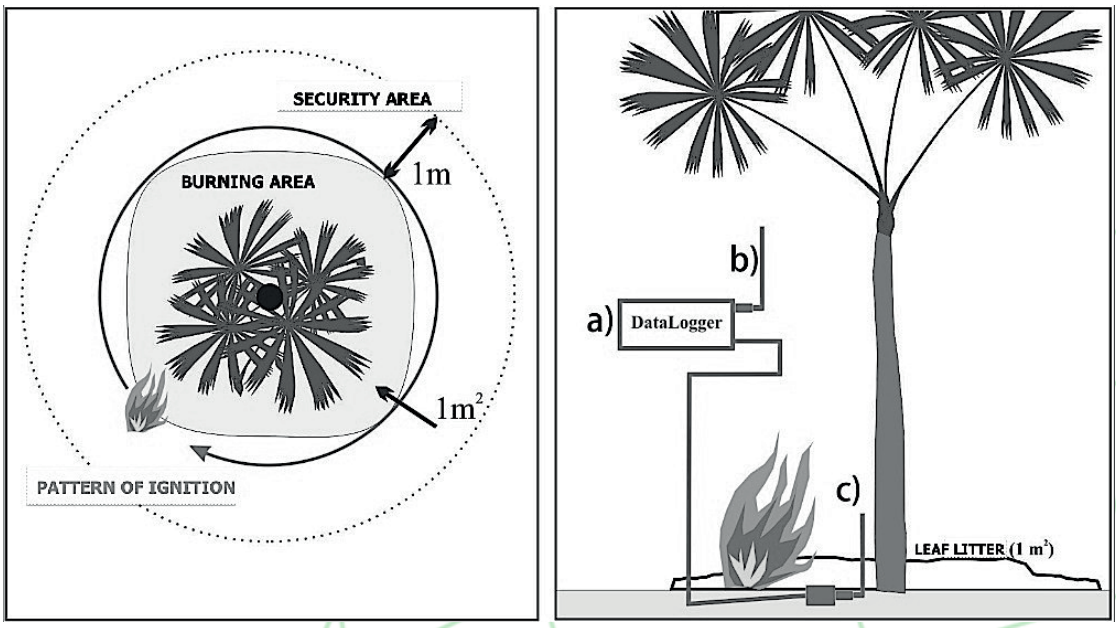

Figure 2. Diagrams of burn methods. On the left, top view showing the $1 \mathrm{~m} 2$ burning area and the security area without litter. On the right, the temperature monitoring method: a) datalogger; b) ambient temperature sensor; c) plant basal $\mathrm{K}$ sensor, positioned $10 \mathrm{~cm}$ above the ground and $5 \mathrm{~cm}$ from the stem surface.

Postfire palm resprouting in the amazonian forest: are underground stems an advantage? Marcus Vinicius Athaydes Liesenfeld, Gil Vieira

Revista Perspectivas Rurales by Universidad Nacional is licensed under a Creative Commons Reconocimiento-NoComercial- 
Table 1.

Underground-stemmed (A) and Aerial stem (B) species sampled in the postfire experiment in a western Amazon forest (Acre - Brazil), with n: number of individuals and ramets clonability.

\begin{tabular}{|c|c|c|c|}
\hline A) Underground-stemmed species ${ }^{1}$ & $\mathbf{n}$ & Popular name & Clonability \\
\hline Astrocaryum ulei Burret & 13 & tucum & Yes \\
\hline Attalea butyracea (Mutis exL.f.) Wess.Boer & 15 & jaci & No \\
\hline Attalea maripa (Aubl.) Mart. & 12 & inajá, maripa & Yes \\
\hline Geonoma acaulis Mart. & 17 & ubim & No \\
\hline Oenocarpus bataua Mart. & 22 & patauá, patawa & No \\
\hline \multicolumn{4}{|l|}{ B) Aerial stem species } \\
\hline Bactris maraja Mart. & 14 & marajá & Yes \\
\hline Chamaedorea pauciflora Mart. & 11 & ubim & Yes \\
\hline Euterpe precatoria Mart ${ }^{2}$. & 27 & açaí-solteiro, assai & No \\
\hline Geonoma deversa (Poit.) Kunth & 12 & ubim & No \\
\hline Hyospathe elegans Mart. & 26 & ubim & Yes \\
\hline
\end{tabular}

Note: own elaboration

1. For A. ulei, A. butyracea, A. maripa, and O. bataua, only understory juveniles was sampled (underground stem phase). 2. Only juveniles was sampled.

Resprouts are common in palms submitted to environmental impacts, fires for example (Barot et al., 2005; Gehring et al., 2011). Here, after 140 days of surface fire experiment, it was found that the basal resprout was more frequent for individuals with aerial stems $(\mathrm{U}=-3.3 ; p=0.001)$, than for individuals with underground stems (figure 3). Underground-stemmed species have more apical regrowth than for the aerial stems species $(\mathrm{U}=4.7 ; p<0.001)$. The number of resprouting individuals is greater in species with clonal ability than in species without it; both for basal resprout: $(\mathrm{U}=-4.3 ; p<0.001 ; \mathrm{N}=169)$, and for apical regrowth $(\mathrm{U}=-3.5 ; p<0.001 ; \mathrm{N}=169)$. Non-clonal species had proportionally greater numbers of apical regrowth individuals $(U=4.5 ; p<0.001 ; n=169)$ - figure 4. Bactris maraja has comparatively the largest result for individual resprouting $(\mathrm{H}=22.39 ;$ g.l. $=4 ; p<0.001 ; \mathrm{n}=90)$.

There was no variation among the aerial stem species for mortality (Kruskal-Wallis Test, $\mathrm{H}=5.49$, g.l. $=4 ; p=0.240 ; \mathrm{n}=90)$, apical regrowth $(\mathrm{H}=3.93$, g.l. $=4 ; p=$ $0.415 ; \mathrm{n}=90)$ and survival $(\mathrm{H}=8.42$, g.l. $=4 ; p=0.077 ; \mathrm{n}=90)$ (table 2). Only E. precatoria did not display basal resprouting. E. precatoria's strategy was the apical regrowth. A similar situation was observed in Hyospathe elegans and Geonoma deversa. However, for these species, there are also lateral and basal sprouts. 
Table 2.

Postfire fate results of underground and aerial palm stems, in a western Amazon forest (Acre - Brazil). n: number of individuals. Total resprout $=$ basal resprout + apical regrowth + basal \& apical. Total mortality = no sprout + fail sprout. Surv.: individual survival with no sprout.

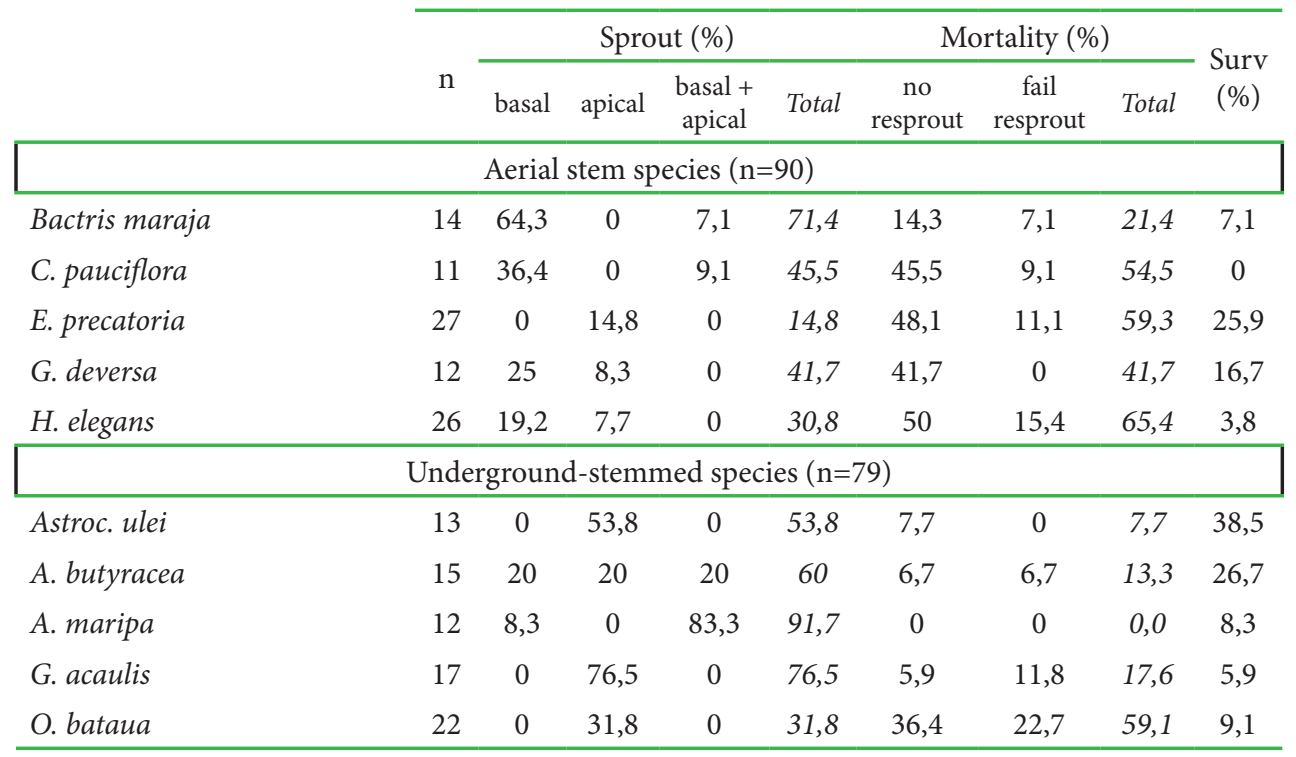

Note: own elaboration

Juveniles of underground-stemmed species had positive response to fire, and there is a difference between resprouting results $(\mathrm{H}=9.87, \mathrm{~g} .1 .=4 ; p<$ $0.001 ; \mathrm{n}=79)$. Attalea maripa obtained the best performance considering total resprout, between species $(91.7 \%)$. Oenocarpus bataua exhibited the lowest resprout success with $31.8 \%$, (table 2). Only Attalea butyraceae and A. maripa had basal resprout, sending new shoots near the base of the stem. Geonoma acaulis, Astrocaryum ulei and Oenocarpus bataua had a rather similar resprouting strategy: after fire, apical meristem regrows.

The postfire mortality was also assessed, showing no difference among underground-stemmed species (Kruskal-Wallis $\mathrm{H}=13.01 ; \mathrm{g} . \mathrm{l} .=4 ; p=0.01 ; \mathrm{n}=79$ ). Oenocarpus bataua had a comparatively greater proportion of mortality (59.1\%). Attalea maripa showed no mortality recorded up to $\sim 140$ days postfire. There was a higher mortality in aerial stem species than in underground-stemmed species (Test of Mann-Whitney, $\mathrm{U}=7 ; p<0.001$ ). Among all underground-stemmed species sampled, G. acaulis is the only one that actually has all its life phases in the forest understory, without aerial stem developing. This species had almost $80 \%$ of its individuals displaying apical regrowth.

Postfire palm resprouting in the amazonian forest: are underground stems an advantage? Marcus Vinicius Athaydes Liesenfeld, Gil Vieira

Revista Perspectivas Rurales by Universidad Nacional is licensed under a Creative Commons Reconocimiento-NoComercialCompartirIgual 4.0 Internacional License.

Creado a partir de la obra en http://revistas.una.ac.cr/index.php/perspectivasrurales. 
The present study was the first to quantify and describe the postfire palm resprouting abilities, in the Amazon rainforest. Unexpectedly the fire was unable to eliminate the totality of the individuals from all species subjected to this experiment. Furthermore, strategies were observed which have enabled the resilience of individuals in the community, e.g.: by apical regrowth.

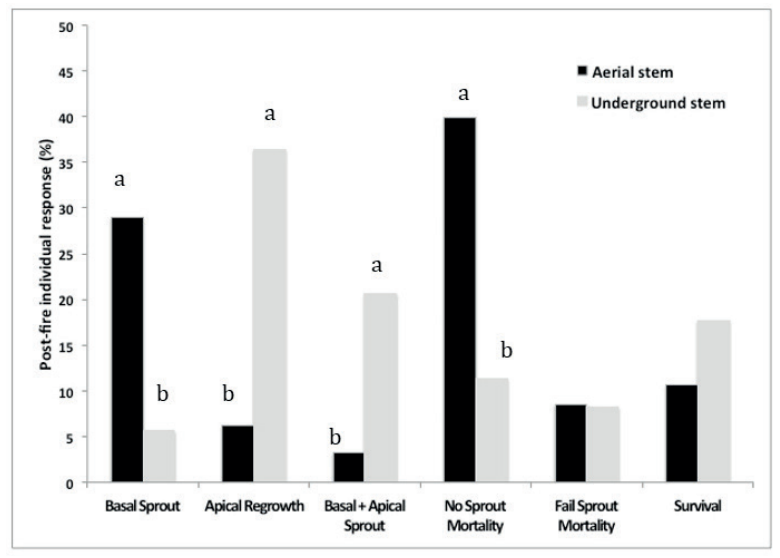

Figure 3. Postfire individual response results ( 140 days), for aerial and underground- stemmed palm species (10 species, $\mathrm{n}=169)$, in a western Amazon Forest, Acre - Brazil. Fail sprout: sprout followed by mortality. Axis y limited to $50 \%$ for better visualization. Lateral sprout is not shown. Letters above the bars indicate significance by Mann-Whitney test $(p<0.05)$.
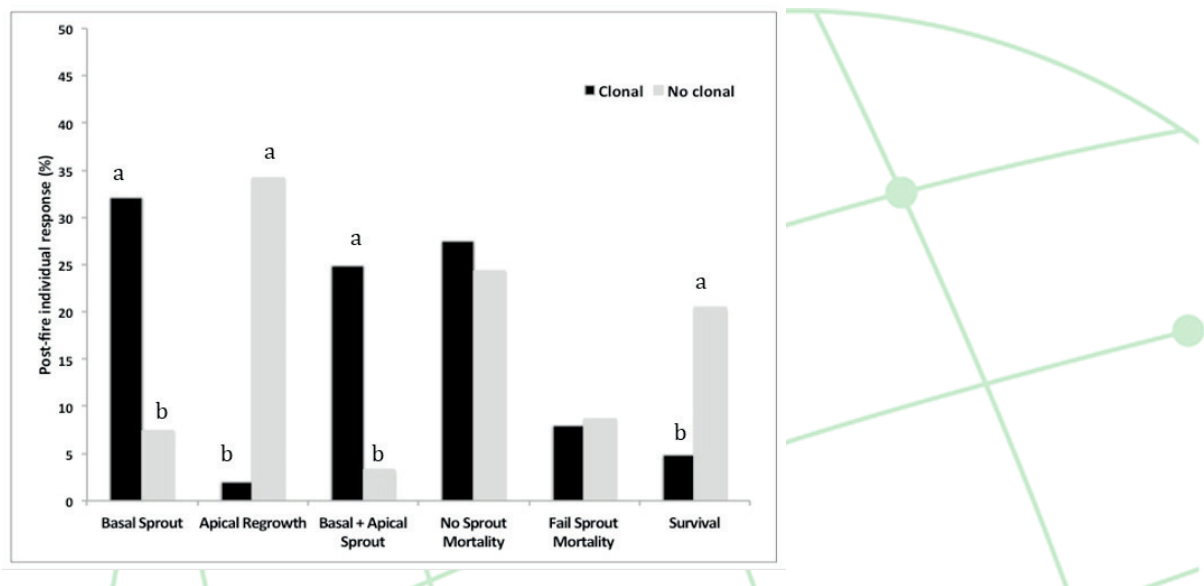

Figure 4. Postfire individual response results ( 140 days), for clonal and no clonal palm species (10 species, $n=169$ ), in a western Amazon Forest, Acre - Brazil. Fail sprout: followed by mortality. Axis y limited to $50 \%$ for better visualization. Lateral sprout is not shown. Letters above the bars indicate significance by Mann-Whitney test $(p<0.05)$.

Postfire palm resprouting in the amazonian forest: are underground stems an advantage? Marcus Vinicius Athaydes Liesenfeld, Gil Vieira 
Since the apical meristem is secured on the forest underground, below the litter and the ground level, a greater survival success was expected for underground-stemmed species (also observed by Simões and Marques, 2007). High fire temperatures may not affect the apical meristem tissues of the plant because the temperature profile in a surface fire is lowered below ground level (Certini, 2005). All species in the present study have had some success in apical regrowth. This could be a strong indication that the apical meristem is in fact protected due to its buried habit.

In addition to the leaves, petioles and sheaths attached to the base of the stem, another morphological factor that would be influencing the apical regrowth is the "saxophone stem" (Tomlinson, 1979). The underground apical meristem appears curved and associated to the base of the sheaths of the leaves, forming a quite compact set of tissues, like a shield, which could reduce the heat flux at the apical meristem. Being so, the apical meristems in the saxophone stems are protected from the heat (Flinn and Wein, 1977).

Attalea maripa (maripa palm) presents regular distribution in the tropical forest (Salm, 2005); however, it is already possible to observe in the cattle fields of west of Acre, in a similar situation in the east of the Pará state, where babassu (Attalea speciosa) populations dominate the impacted landscapes (Rocha et al., 2016). Similarly A. maripa populations can increase in fire impacted forest edges, or in the adjacent open areas. Among questions to be pursued, is A. maripa a possibility to reach greater inter-specific competitive advantage under an increased fire influence? This could exclude food economic palm species from the forest edges, such as: assai (Euterpe precatoria) and patawa (Oenocarpus bataua).

Withglobalclimatechange, forestsarealreadysufferingwith evapotranspiration elevation, air relative humidity reduction, temperature rise at the edges and groundwater level decrease. The risk of fire outbreaks in the forest edges penetrating into the interior has increased considerably (Morton et al., 2013; Balch et al., 2013; IPCC WGII, 2014). With the intensification of the adverse effects of climate change, the intensity of fires also increase, and consequently the severity of fires on the plants (Laurance et al., 2011; Armenteras et al., 2013). For all these reasons, it is now even more useful and necessary to recognize plant survival skills and their postfire resilience strategies.

Postfire palm resprouting in the amazonian forest: are underground stems an advantage? Marcus Vinicius Athaydes Liesenfeld, Gil Vieira 


\section{Conclusions}

Palm species in the western Amazon have differential responses to fire impact. Fire causes higher mortality among aerial stem species than in underground-stemmed species. Resprouting is greater in the clonal species. Survival of underground-stemmed individuals, at least in some life phase, can be ensured by a underground apical meristem. This could consist in a postfire recovery advantage. The apical regrowth was an important strategy for recovery after fire, for all species sampled. Attalea maripa (maripa palm) responded positively to the fire impact, and so its population can increase in fire impacted forest edges. On the other side, Euterpe precatoria (assai) and Oenocarpus bataua (patawa) were quite damaged by the fire impact; this could lead to a population impact on these important food economical species in fire impacted edges.

\section{Acknowledgements}

The authors would like to thank CAPES for the research grant; Seu Darci, owner who ceded his area for research; the indispensable field helpers; and S.D. Mendonça for helpful comments.

\section{References}

Abrahamson, W. G. (1999). Episodic Reproduction in Two Fire-Prone Palms, Serenoa repens and Sabal etonia (Palmae). Ecology, 80(1):100-115. DOI: doi.org/10.2307/176982

Aponte, H., Kahn, F., \& Millán, B. (2011). Vegetative adaptability of the Peruvian palm Astrocaryum perangustatum to deforestation. Revista Peruana de Biología, 18(2): 179-183. DOI: $\underline{\text { doi.org/10.15381/rpb.v18i2.225 }}$

Armenteras, D., González, T., \& Retana, J. (2013). Forest fragmentation and edge influence on fire occurrence and intensity under different management types in Amazon forests. Biological Conservation, 159: 73-79. DOI: doi.org/10.1016/j.biocon.2012.10.026

Balch, J. K., Massad, T.J., Brando, P.M., Nepstad, D.C., \& Curran, L. M. (2013). Effects of high-frequency understorey fires on woody plant regeneration in southeastern Amazonian forests. Philosophical Transactions of the Royal Society B: Biological Sciences, 368(1619): 20120157-20120157. DOI: $10.1098 / \mathrm{rstb} .2012 .0157$

Postfire palm resprouting in the amazonian forest: are underground stems an advantage? Marcus Vinicius Athaydes Liesenfeld, Gil Vieira 
Barot, S., Mitja, D., Miranda, I., Meija, G.D., \& Grimaldi, M. (2005). Reproductive plasticity in an Amazonian palm. Evolutionary Ecology Research, 7(7): 1051-1065. https://www.researchgate.net/publication/228676243 Reproductive plasticity in an Amazonian palm

Bond, W. J. \& Midgley, J. J. (2003). The Evolutionary Ecology of Sprouting in Woody Plants. International Journal of Plant Sciences, 164 (S3): S103S114. DOI: doi.org/10.1086/374191

Certini, G. (2005). Effects of fire on properties of forest soils: a review. Oecologia, 143(1):1-10. DOI: 10.1007/s00442-004-1788-8

Clarke, P. J., Lawes, M.J., Midgley, J.J., Lamont, B.B., Ojeda, F., Burrows, G., ... Knox, K.J.E. (2013). Resprouting as a key functional trait: how buds, protection and resources drive persistence after fire. The New Phytologist, 197(1):19-35. DOI: 10.1111/nph.12001

Cochrane, M., Alencar, A., Schulze, M., Souza Jr, C., Nepstad, D., Lefebvre, P., \& Davidson, E. (1999). Positive feedbacks in the fire dynamic of closed canopy tropical forests. Science, 284(5421):1832-1835. DOI: $\underline{10.1126 /}$ science.284.5421.1832

Coe, M. T., Marthews, T. R., Costa, M.H., Galbraith, D.R., Greenglass, N.L., Imbuzeiro, H.M.A., ... Wang, J. (2013). Deforestation and climate feedbacks threaten the ecological integrity of south-southeastern Amazonia. Philosophical transactions of the Royal Society of London. Series B, Biological sciences, 368(1619):20120155. DOI: 10.1098/rstb.2012.0155

Flinn, M. A., and Wein, R. W. (1977). Depth of underground plant organs and theoretical survival during fire. Canadian Journal of Botany, 55(19): 2550-2554. DOI: $\underline{\text { doi.org/10.1139/b77-291 }}$

Gehring, C., Zelarayánet, M.L.C., Almeida, R.B., Moraes, F.H.R. (2011). Allometry of the babassu palm growing on a slash-and-burn agroecosystem of the eastern periphery of Amazonia. Acta Amazonica, 41(1), 127-134. DOI: dx.doi.org/10.1590/S0044-59672011000100015

Hirota, M., Holmgren, M., Van Nes, E.H. \& Scheffer, M. (2011). Global Resilience of Tropical Forest and Savanna to Critical Transitions. Science, 334(10):232-234. DOI: 10.1126/science.1210657 
Keeley, J. E., Pausas, J.G., Rundel, P.W., Bond, W.J., \& Bradstock, R.A. (2000). Fire as an evolutionary pressure shaping plant traits. Trends in plant science, p 1-6. DOI: 10.1016/j.tplants.2011.04.002

Krieger F, G. C., Bufacchi, P., Santos, J.C., Gurgel V, C.A., Alvarado, E.C., Mell. W., \& Carvalho Jr, J.A. (2017). Probability of surface fire spread in Brazilian rainforest fuels from outdoor experimental measurements. European Journal of Forest Research, 1-16. DOI: doi.org/10.1007/s10342-016-1023-2

Laurance, W. F., Camargo, J.C., Luizão, R.C., Laurence, S.G., Pimm, S.L., Bruna, E. M., ... Lovejoy, T.E. (2011). The fate of Amazonian forest fragments : A 32-year investigation. Biological Conservation, 144(1):56-67. DOI: 10.1016/j.biocon.2010.09.021

Liesenfeld, M.V.A., Vieira, G., \& Miranda, I. P. A. (2016). Ecologia do fogo e o impacto na vegetação da Amazônia. Pesquisa Florestal Brasileira, 36(88):505-517. DOI: doi.org/10.4336/2016.pfb.36.88.1222

Michaletz, S. \& Johnson, E. (2007). How forest fires kill trees: A review of the fundamental biophysical processes. Scandinavian Journal of Forest Research, 22(6): 500-515. DOI: 10.1080/02827580701803544

Miola, D. T., Correia, H.V., Fernández, G. W., \& Negriros, D. (2010). The effect of fire on phenology of Syagrus glaucescens Glaz. ex Becc. (Arecaceae). Neotropical Biology and Conservation, 5(3): 146-153. DOI: 10.4013/ nbc.2010.53.02

Morton, D. C., Le Page, Y., DeFries, R. Collatz, G.J., \& Hurtt, G.C. (2013). Understorey fire frequency and the fate of burned forests in southern Amazonia. Philosophical transactions of the Royal Society of London. Series B, Biological sciences, 368(16199): 20120163. DOI: 10.1098/rstb.2012.0163

Pausas, J.G. \& Keeley, J.E. (2014). Evolutionary ecology of resprouting and seeding in fire-prone ecosystems. New Phytologist, 204(1): 55-65. DOI: doi.org/10.1111/nph.12921

Rocha, G. P., Vieira, D.L.M., \& Simon, M.F. (2016). Fast natural regeneration in abandoned pastures in southern Amazonia. Forest Ecology and Management, 370: 93-101. DOI: doi.org/10.1016/j.foreco.2016.03.057

Postfire palm resprouting in the amazonian forest: are underground stems an advantage? Marcus Vinicius Athaydes Liesenfeld, Gil Vieira 
Rogers, B.M., Soja, A.J., Goulden, M.L., \& Randerson, J.T. (2015). Influence of tree species on continental differences in boreal fires and climate feedbacks. Nature Geoscience, 8: 228-234. DOI: doi.org/10.1038/ngeo2352

Salm, R. (2005). The importance of forest disturbance for the recruitment of the large arborescent palm Attalea maripa in a seasonally-dry Amazonian forest. Biota Neotropica, 5(1): 35-41. DOI: doi.org/10.1590/ s1676-06032005000100004

Silvestrini, R. A., Soares-Filho, B.S., Nepstad, D., Coe, M., Rodrigues, H., \& Assunção, R. (2011). Simulating fire regimes in the Amazon in response to climate change and deforestation. Ecological Applications, 21(5): 1573-1590. DOI: $\underline{10.1890 / 10-0827.1}$

Simões, C. G. \& Marques, M. (2007). The role of sprouts in the restoration of Atlantic Rainforest in southern Brazil. Restoration Ecology, 15(1): 5359. DOI: doi.org/10.1111/j.1526-100x.2006.00189.x

Tomlinson, P. B. (1979). Systematics and ecology of the Palmae. Annual review of ecology and systematics, 10(1): 85-107. DOI: doi.org/10.1146/ annurev.es.10.110179.000505

Uhl, C. \& Kauffman, J. B. (1990). Deforestation, Fire Susceptibility, and Potential Tree Responses to Fire in the Eastern Amazon. Ecology, 71(2): 437-449. DOI: $10.2307 / 1940299$

Verdú, M., Pausas, J.G., Segarra-Moragues, J.G., \& Ojeda, F. (2007). Burning phylogenies: fire, molecular evolutionary rates, and diversification. Evolution; international journal of organic evolution, 61(9): 2195-2204. DOI: $10.1111 / \mathrm{j} .1558-5646.2007 .00187 . \mathrm{x}$

Vesk, P.A. \& Westoby, M.S. (2004). Sprouting ability across diverse disturbances and yegetation types worldwide. Journal of Ecology, 82(2): 911-320. DOI: $10.1111 / j .0022-0477.2004 .00871 . x$

WGII, IPCC. (2014). Climate change 2014: impacts, adaptation and vulnerability. Working Group II, IPCC 5th Assessment Report, http:// www.ipcc.ch

Wuschke, M. (1999). Fire Resistance in a Queensland Livistona. Palms (Principes), 43(3): 140-144. 